\title{
EKSISTENSI KAJIAN TAUHID DALAM KEILMUAN USHULUDDIN
}

\author{
Saidul Amin \\ saidulamin@uinsusyqa.ac.id \\ Universitas Islam Negeri Sultan Syarif Qasim
}

\begin{abstract}
Abstrak: The study of Tawheed in Islam is the regional foundation for discussion of aqeedah.in this case aqeedah is something very important and fundamental in the formation of good character in the life of a Muslim, which is used as a pillar and foundation of religion, so as to be able to motivate a person in the form of trust and faith. therefore, aqeedah as the foundation for establishing Islamic buildings is the beginning of noble character. If someone has strong Aqeedah, surely they will carry out their worship in an orderly, noble manner, and bermu'amalat well. all the worship that we carry out if without the foundation of Aqeedah then the worship will not be accepted.
\end{abstract}

Keywords: Tawheed, aqeedah, belief and faith

\section{A. PENDAHULUAN}

Islam sebagai agama yang
sempurnadan berada dalam
dirasakan dalam kehidupan dengan melaksanakannya secara sempurna. Dalam kaitan ini, kesempurnaan agama seseorang dapat kita lihat dari aqidahnya, dimana akidah tersebut merupakan keyakinan atas sesuatu yang di dalamnya mencakup segala sesuatu yang berkaitan dengan rukun iman, baik tentang keyakinan kepada Tuhan, para malaikat, kitab-kitab, para rasul, serta takdir baik dan buruk. Sumber daripada akidah Islam adalah Alquran dan Sunnah, yang secara keilmuan akademis terakomodir dalam kajian tauhid.
Dalam kajian tauhid, posisi aqidah mendapatkan perhatian yang sangat besar karena menyadari bahwa ibadah tanpa Aqidah hanyalah sia-sia dan begitu juga sebaliknya. Untuk meluruskan paradigma akan umat tentang sebuah Aqidah maka untuk mengenalnya Tauhid mencangkup pembahasan Aqidah didalamnya, dengan membaginya menjadi beberapa ruang lingkup dan menjelaskan keberadaan fungsi dari Aqidah. Meskipun demikian, kajian tauhid mempunyai nama lain sebagai sebuah terminologi, yaitu ilmu ushuluddin, ilmu kalam, ilmu aqidah, dan teologi Islam.

Pembahasan mengenai tauhid merupakan hal yang paling penting dalam agama Islam, dimana tauhid mengambil peranan penting dalam membentuk 
pribadi-pribadi yang tangguh, selain juga sebagai inti atau akar daripada Aqidah Islamiyah. Namun rupanya saat ini pembahasan masalah 'aqidah menjadi sesuatu yang terkesampingkan dalam kehidupan, kencenderungan masyarakat yang hedonis dengan persaingan hidup yang begitu ketat, sehingga urusan-urusan dunia menjadi suatu hal yang menyita perhatian manusia daripada hal-hal lainnya, termasuk masalah keberagamaan, sehingga akan didapati banyak sekali penyimpangan demi penyimpangan yang terjadi di tengah-tengah umat Islam

\section{B. PEMAHAMAN DAN TERM-TERM DALAM KAJIAN TAUHID}

Kata tauhid berasal dari bahasa Arab, masdar dari kata wahhada ( وَحَّدَ ) yuwahhidu ( يُوَجِدُ ). Secara etimologi, tauhid berarti keesaan.Maksudnya, iktikad atau keyakinan bahwa Allah adalah Esa; Tunggal; Satu. Pengertian ini sejalan dengan pengertian tauhid yang digunakan dalam bahasa Indonesia, yaitu "keesaan Allah"; mentauhidkan berarti "mengakui keesaan Allah; mengesakan Allah." Secara istilah syar'i, tauhid berarti mengesakan Allah dalam hal mencipta, menguasai, mengatur dan memurnikan (mengikhlaskan) peribadahan hanya kepada-Nya, meninggalkan penyembahan kepada selain-Nya serta menetapkan asma'ul husna dan sifat al- 'ulya bagi-Nya dan mensucikan-Nya dari kekurangan dan cacat.

Asal makna "tauhid" ialah meyakinkan, bahwa Allahadalah "satu", tidak ada syarikat bagi-Nya. Oleh sebab itu, sebab dinamakan "Ilmu Tauhid", ialah karena bahagiannya yang terpenting, menetapkan sifat "wahdah" (satu) bagi

\footnotetext{
${ }^{1}$ Yusran Asmuni, Ilmu Tauhid,(Jakarta: RakaGrafindo Persada, 1996), cet. Ke-3, h. 1.
}

Allah dalam zat-Nya dan dalam perbuatan-Nya menciptakan alam seluruhnya dan bahwa Ia sendiri-Nya pula tempat kembali segala alam ini dan penghabisan segala tujuan. ${ }^{2}$ Misalnya Muhammad Abduh menjelaskan:

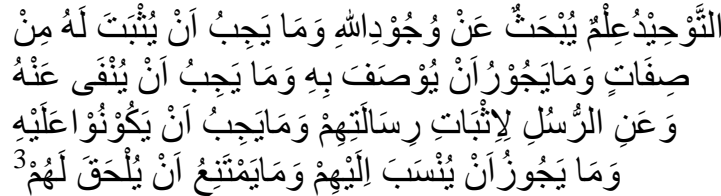

"Tauhid ialah suatu ilmu yang membahas tentang wujud Allah, sifatsifat yang wajib tetap pada-Nya, sifatsifat yang boleh disifatkan kepadaNya, dan tentang sifat-sifat yang sama sekali wajib dilenyapkan padaNya.Juga membahas tentang rasulrasul Allah, meyakinkan kerasulan mereka, apa yang boleh dihubungkan (dinisbatkan) kepada mereka, dan apa yang terlarang menghubungkannya kepada diri mereka."

Tauhid dalam kajian disebut sebagai ilmu tauhid, yang juga dinamakan sebagai ilmu kalam, karena dalam pembahasannya mengenai eksistensi Tuhan dan hal-hal yang berhubungan dengan-Nya digunakan argumentasiargumentasi filosofis dengan menggunakan logika atau mantik.

Secara lebih rinciHasbi ashShiddieqi menyebutkan alasan mengapa ilmu ini disebutkan ilmu kalam, yaitu:

1. Problema yang diperselisihkan para ulama dalam ilmu ini yang menyebabkan umat Islam terpecahkan dalam beberapa golongan adalah masalah

\footnotetext{
${ }^{2}$ Muhammad Abduh, Risalah Tauhid, (diterjemahkan oleh Firdaus AN), (Jakarta: Bulan Bintang, 1996), cet. Ke-10, h. 5.

${ }^{3}$ Yusman Asmuni, Op.cit., h. 1.
} 
Kalam Allah atau al-Qur'an; apakah ia diciptakan (makhluk) atau tidak (qadim).

2. Materi-materi ilmu ini adalah teori-teori (kalam); tidak ada diantaranya yang diwujudkan ke dalam kenyataan atau diamalkan dengan anggota.

3. Ilmu ini di dalam menerangkan cara atau jalan menetapkan dalil pokok-pokok akidah serupa dengan ilmu mantik.

4. Ulama-ulama mutaakhirin membicarakan di dalam ilmu ini hal-hal yang tidak dibicarakan oleh ulama salaf, seperti pentakwilan ayat-ayat mutasyabihat, pembahasan tentang pengertian qadha, kalam, dan lain-lain.

Ilmu tauhid dinamakan ilmu kalam, dalam hal ini para ahli di bidang ini disebut mutakallimin.Penamaan ilmu tauhid dengan ilmu kalam sebenarnya dimaksudkan untuk membedakan atara mutakallimin dan filosof Islam.Mutakallimin dan filosof Islam mempertahankan atau memperkuat keyakinan mereka sama-sama menggunakan metode filsafat, tetapi mereka berbeda landasan awal berpijak.Mutakallimin lebih dahulu bertolak dari al-Qur'an dan hadits, sementara filosof berpijak pada logika.Meskipun demikian, tujuan yang ingin mereka capai adalah satu, yaitu keesaan dan kemahakuasaan Allah. Dengan kata lain, mereka berbeda jalan untuk mencapai tujuan yang sama.Selanjutnya, ilmu tauhid juga dinamakan ilmu ushuluddin karena obyek bahasan utamanya adalah dasar-dasar agama yang merupakan masalah esensial dalam ajaran Islam. ${ }^{4}$ Begitu pula ketika ilmu ini disebut sebagai kajian didasarkan pada argument bahwa 'aqaid jamak dari 'aqidah.Aqidah berasal dari kata 'aqada yang artinya ikatan.Disebut ilmu tauhid dengan sebutan ilmu aqaid atau ilmu ushuluddin adalah karena pokok pembicaraannya ialah soal-soal pokokpokok kepercayaan agama yang menjadi dasar agama Islam. ${ }^{5}$

Ketika dikaitkan dengan teologi Islam sebagai istilah asing yang sering pula dikenal untuk ilmu tauhid ini.Teologi terdiri dari perkataan "theos" artinya Tuhan dan "logos" yang berarti ilmu (science, study, discourse).Jadi teologi berarti ilmu tentang Tuhan atau ilmu ketuhanan.Dalam encyclopedia everimans yang dikutip oleh Muslim Munaf dikemukakan defenisi teologi sebagai berikut :"Science of religion, dealing therefore with god, and man in his relation to god" (pengetahuan tentang agama, yang karenanya membicarakan tentang Tuhan dan manuisa dalam tertaliannya dengan Tuhan). Banyak penulis yang memandang bahwa teologi bertalian erat dengan agama dan mendefenisikannya sebagai uraian yang bersifat pikiran tentang agama.Akan tetapi, pendapat ini kurang tepat.Karena seorang ahli teologi dapat menjalankan penyelidikannya dengan bebas tanpa tanpa menjadi seorang agamawan.Karena itu lebih tepat dikatakan bahwa teologi dapat bercorak agama (revealed theology) dan dapat pula tidak bercorak agama (natural theology atau philoshopical theology).

\footnotetext{
${ }^{4}$ Ibid.,h. 4-5.

${ }^{5}$ Murni, Tauhid Ilmu Kalam, (Padang :
} The Minangkabau Foundation Press, 2006), cet. Ke-1, h. 5. 
Ringkasnya adalah teologi adalah ilmu yang membicarakan tentang Tuhan dan pertaliannya dengan manusia, baik berdasarkan kebenaran wahyu maupun berdasarkan penyelidikan akal. Untuk menentukan lapangan dan corak pembahasan, perkataan teologi diberi keterangan kualifikasi seperti: teologi filsafat, teologi Khatolik, teologi Kristen, teologi Islam, dan lain-lain.

Berdasarkan pengertian tauhid dan pengertian teologi yang sudah dijelaskan dapatlah ditarik titik persamaan antara ilmu tauhid dengan teologi Islam, sehingga apabila disebut teologi Islam, pengertiannya tidak lain dari ilmu tauhid ${ }^{6}$, yaitu:

a. Kepercayaan tentang Tuhan dengan segala segi-seginya, yaitu termasuk didalamnya soal-soal wujud-Nya, keEsaanNya, dan sifat-sifat-Nya.

b. Pertalian dengan alam semesta, yang berarti termasuk didalamnya persoalan terjadinya alam, keadilan, Qadha dan Qadhar, pengutusan Rasul sekaligus meliputi wahyu, berita ghaib seperti soal akhirat.

Meskipun nama yang diberikan berbeda-beda, namun inti pokok pembahasan ilmu tauhid adalah sama, yaitu wujud Allah dan hal-hal yang berkaitan dengan-Nya. Karena tu, aspek penting dalam ilmu tauhid adalah keyakinan akan adanya Allah Yang Mahasempurna, Mahakuasa, dan memiliki sifat-sifat kemahasempurnaan lainnya. Keyakinan yang demikian pada gilirannya akan membawa kepada keyakinan terhadap adanya malaikat, kitab-kitab, nabi dan rasul, hari akhir, dan melahirkan

\footnotetext{
${ }^{6}$ Ibid, h. 3-4.
}

kesadaran akan tugas dan kewajiban terhadap Khaliq (Pencipta).

Pokok pembahasan ilmu tauhid adalah wujud Allah.dan hal-hal yang berkaitan dengan-Nya. Karena itu, aspek penting dalam ilmu tauhid adalah keyakinan akan adanya Allah Yang Mahasempurna, Mahakuasa, dan memiliki sifat-sifat keMaha sempurnaan lainnya. Tauhid tidak hanya sekedar diketahui dan dimiliki oleh seseorang, tetapi lebih dari itu, ia harus dihayati dengan baik dan benar. Apabila tauhid telah dimiliki, dimengerti, dan dihayati dengan baik dan benar, kesadaran seseorang akan tugas dan kewajibannya sebagai hamba Allah akan muncul sendirinya. Keesaan Allah mencakup empat bagian:

a. Keesaan Dzat

Keesaan Dzat mengandung pengertian bahwa seseorang harus percaya bahwa Allah SWT. tidak terdiri dari unsur-unsur, atau bagian- bagian, karena bila Dzat Yang Mahakuasa itu terdiri dari dua unsur atau lebih berarti Allah membutuhkan unsur atau bagian. Dzat Allah pasti tidak terdiri dari unsur atau bagian-bagian betapapun kecilnya, karena jika demikian, Allah tidak lagi menjadi Tuhan. Kita tidak dapat membayangkan jika Allah membutuhkan sesuatu padahal al-Qur'an menegaskan:

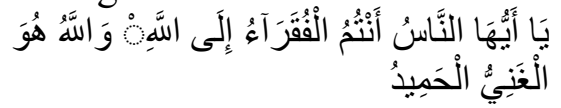

"Wahai seluruh manusia, kamulah yang butuh kepada Allah dan Allah Mahakaya tidak membutuhkan sesuatu lagi Maha Terpuji” (QS. Fațir : 15).

b. Keesaan Sifat

Adapun keesaan sifat-Nya, maka itu antara lain berarti bahwa Allah memiliki sifat yang tidak sama dalam substansi dan kapasitasnya dengan sifat makhluk, walaupun dari segi bahasa kata yang digunakan untuk menunjuk sifat 
tersebut sama. Sebagai contoh, kata rahīm merupakan sifat bagi Allah, tetapi juga digunakan untuk menunjuk rahmat atau kasih sayang makhluk.Namun substansi dan kapasitas rahmat dan kasih sayang Allah berbeda dengan rahmat makhlukNya.Allah Esa dalam sifatNya, sehingga tidak ada yang menyamai substansi dan kapasitas sifat tersebut.Seperti firman Allah dalam QS. Al-Fatihah: 3.

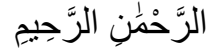

"Maha Pemurah lagi Maha Penyayang". (QS. al-Fatihah : 3).

c. Keesaan Perbuatan

Keesaan ini mengandung arti bahwa segala sesuatu yang berada di alam raya ini, baik sistem kerjanya maupun sebab dan wujud- Nya, kesemuanya adalah hasil perbuatan Allah semata.Apa yang dikehendaki-Nya terjadi, dan apa yang tidak dikehendaki-Nya tidak akan terjadi, tidak ada daya (untuk memperoleh manfaat), tidak pula kekuatan (untuk menolak madarat), kecuali bersumber dari Allah. Tetapi ini bukan berarti bahwa Allah., berlaku sewenang-wenang, atau bekerja tanpa sistem yang ditetapkan-Nya. Keesaan perbuatan-Nya dikaitkan dengan hukum-hukum, atau takdir dan sunnatullah yang ditetapkan-Nya.Dalam mewujudkan kehendak-Nya Dia tidak membutuhkan apapun. Sebagaimana firman-Nya,

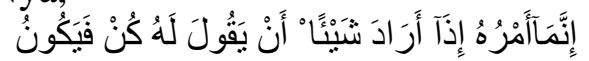

"Sesungguhnya keadaan-Nya bila

Dia menghendaki sesuatu hanyalah berkata, 'Jadilah!' Maka jadilah ia." (QS. Yasin : 82).

\section{d. Keesaan dalam Beribadah Kepada-Nya \\ Mengesakan Allah dalam} beribadah yaitu melaksanakan segala sesuatu karena Allah, baik sesuatu itu dalam bentuk ibadah mahḍah (murni), maupun selainnya. Walhasil, keesaan Allah dalam beribadah kepada-Nya adalah dengan melaksanakan apa yang tergambar dalam firman-Nya. Apabila seseorang telah menganut akidah tauhid dalam pengertian yang sebenarnya, maka akan lahir dari dirinya berbagai aktivitas, yang kesemuanya merupakan ibadah kepada Allah, baik ibadah dalam pengertiannya yang sempit (ibadah murni) maupun pengertiannya yang luas.

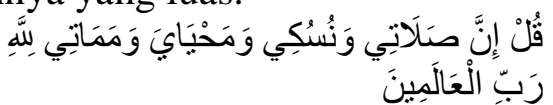

"Katakanlah, Sesungguhnya shalatku, ibadahku, hidupku, dan matiku hanya karena Allah, Pemelihara seluruh alam.” (QS. al-An'am : 162) ${ }^{7}$

Berdasarkan pokok bahasan dalam kajian tauhid di atas tersebut, maka tauhid diklasifikasikan kepada tauhid Rububiyah, tauhid Uluhiyah, dan tauhid Ubudiyah.

\section{Tauhid Rububiyah}

Tauhid rububiyah, rububiyah adalah kata yang dinisbatkan kepada salah satu nama Allah, yaitu Rabb ${ }^{\text {ee }}$. Nama ini mempunyai beberapa arti, antara lain: $A l$ Murabbi (pemelihara),al-Nashir (penolong), al-Malik (pemilik), alMushlih (yang memperbaiki), al-Sayyid (tuan). Dalam terminologi syari'at Islam, istilah tauhid rububiyyah berarti percaya bahwa hanya Allah satu-satunya pencipta, pemilik, pengendali alam raya yang dengan takdirnya-Nya Ia menghidupkan dan mematikan serta mengendalikan alam dengan sunnah-sunnah-Nya".Dalam pengertian ini istilah tauhid rububiyah belum terlepas dari akar makna bahasanya.Sebab Allah adalah pemelihara makhluk, para rasul dan wali-wali-Nya

\footnotetext{
${ }^{7}$ https://www.bacaanmadani.com/2018/01 /pokok-pembahasan-ilmu-tauhid.html.
} 
dengan segala spesifikasi yang telah diberikannya kepada mereka.

Tauhid rububiyah mencakup dimensi-dimensi keimanan berikut ini: Pertama, beriman kepada perbuatanperbuatan Allah yang bersifat umum. Misalnya, menciptakan, memberi rizki, menghidupkan, mematikan, menguasai.Kedua, beriman kepada takdir Allah.Ketiga, beriman kepada zat Allah.Landasan tauhid rububiyah adalah dalil-dalil berikut ini:

$$
\text { الْحَمْدُاللهِهِ ربَ العالمين }
$$

Artinya:"Segala Puji Bagi Allah Rabb Semesta Alam.”(QS. Al-Fatihah: 1). Makna Rabb pada ayat diatas adalah bahwa Allah adalah Pencipta mereka, Yang menguasai, Yang memperbaiki dan Yang memelihara dengan segala nikmat dan anugerah-Nya. ${ }^{8}$ ذالِكُمُ اللهُ رَبهُعُمْ لااله الآهو, خالق كلّ شيء فاعبدوه

Artinya: Itulah Allah Tuhan Kamu, tidak ada tuhan selain Dia,Pencipta segala sesuatu. (Q.S. Al-An'am,6:102).

Bahwasanya Allah lah yang memberi rizki kepada semua makhluk, sebagaimana firman Allah:

$$
\text { وما من دآبّة في الارض الاّ علي الله رزقها }
$$

Artinya: Dan tidak ada suatu binatang melata pun dibumi melainkan Allah yang memberi rizki.(Q.S Hud:11:6).

2. Tauhid Uluhiyah

Tauhid uluhiyah adalah Percaya sepenuhnya bahwa Allah-lah yang berhak menerima semua peribadatan makhluk, dan hanya Allah sajalah yang sebenarnya yang harus disembah.Manusia bersujud kepada Allah, Allah tempat meminta, Allah tempat mengadukan nasibnya,

\footnotetext{
${ }^{8}$ Abdul Aziz bin Muhammad Alu Abdul Lathif,Pelajaran Tauhid Untuk Tingkat Lanjutan.(Jakarta:Darul Haq,1998), cet. Ke-1, h. 10.
}

manusia wajib menaati perinta dan menjauhi larangan-Nya. Semua yang berupa kebatilan langsung kepada Allah, tanpa perantara(wasilah).Allah melarang kita menyembah selain-Nya seperti menyembah batu, menyembah matahari, maupun menyembah manusia. Semua itu adalah perbuatan syirin yang sangat besar dosanya dan dibenci oleh Allah, bahkan Allah tidak akan mengampuni dosa syirik itu. $^{9}$

Berikut firman firmal Allah tentang tauhid Uluhiyah: و الهكم اله وحد لااله الا هو الرحمن الرحيم (البقرة:163)

Artinya: Dan Tuhan kamu adalah Tuhan yang maha Esa, tidak ada tuhan selain Dia, Yang Maha Pengasih Maha Penyayang.

Ilah artinya adalah ma'luh maksudnya, yang disembah dengan penuh kecintaan dan pengagungan. Yakni mengesakan Allah dengan segala bentuk ibadah, sehingga kita tidak berdoa kecuali kepada Allah.Tauhid Uluhiyah inilah yang diingkari oleh orang-orang kafir,baik pada zaman dahulu maupun sekarang. Alla berfirman:

$$
\text { اجعل الالهة الها واحد انّ هذا لشيء }
$$

عجاب(ص:5)

Artinya: Apakah dia menjadikan tuhan tuhan itu Tuhan yang satu saja? Sungguh, ini benar-benar sesuatu yang sangat mengherankan

\section{TauhidUbudiyah}

Kata ubud berasal dari kata kerja 'Abada yang berarti mengabdikan diri(Ibadah). Beribadah kepada allah dengan menyembah kepada-Nya. Penyembahan disini bukan bermaksud Allah berhajat disembah hambanya karena Allah tidak ingin disembahakan tetapi

\footnotetext{
${ }^{9}$ Zainuddin,Ilmu Tauhid Lengkap,
} (Jakarta: Rineka Cipta,1996), cet. Ke-2, h. 17. 
penyembahan disini merupakan ketaatan,kepatuhan,ketumbuhan antara hamba dengan Tuhannya.Antara makhluk dengan khaliknya tidak ubahnya kita atau kepatuhan ketundukannya seorang anak terhadap orang tua. Seorang karyawan kepada pimpinannya yang semua kewajiban dilakukan dengan penuh rasa tanggung jawab, hanya saja didalam ketaatan menjalankan kewajiban tidak terdapat unsur benci sedikitpun kepadanya. Dengan selalu menjalankan perintah-perintahNya dan menjauhi segala larangan-laranganNya. ${ }^{10}$

Ibadah yang semata-mata mengingat perintah Allah Swt.Seperti dalam firman-Nya:

$$
\text { وقضي ربك الا تعبدو آ الاّ اياه وبالو الدين }
$$$$
\text { احسانا }
$$

Artinya: Dan Tuhan mu telah memerintahkan supaya kamu jangan menyembah selain Dia dan hendaklah kamu berbuat baik kepada ibu bapakmu dengan sebaik-baiknya.(Q.S Al-Isra:23).

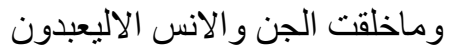

Artinya:Dan tidaklah aku menciptakan jin dan manusia, melainkan supaaya mereka menyembah kepadaKu(Q.S. Adz-Dzariyat:56).

$$
\text { ان الله هوربي وربكم فاعبدوه هذا صر اط }
$$
مستقبم

Artinya: Sesungguhnya Allah, Dialah Tuhan kamu, maka sembahlah Dia, Ini adalah jalan yang lurus.

\section{KAJIAN TAUHID DALAM KAWASAN AQIDAH ISLAM}

Akidah secara etimologi berasal dari kata dalam bahasa Arab berasal dari 'aqada-ya'qidu- 'uqdatan wa aqidatan

\footnotetext{
${ }^{10} I b i d ., \mathrm{h} .23$.
}

artinya ikatan atau perjanjian. Kata al'aqdu (العقد) yang berarti ikatan. Kata attautsiqu (التوثقن) yang berarti kepercayaan yang kuat, الاءحكام (al-ihkamu) berarti

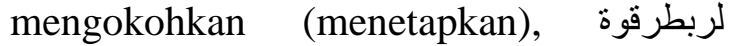
(danar-rabtu bi quwwah) yang berarti mengikat dengan kuat. Secara terminologi adalah keyakinan hati atas sesuatu, yang mengharuskan hati untuk membenarkannya, yang membuat jiwa tenang tentram kepadanya, dan yang menjadi kepercayaan / keyakinan yang bersih dari bimbang dan ragu. Menurut Abu Bakar Jabir al-Jazairy mengatakan bahwa Aqidah yaitu sejumlah kebenaran yang dapat diterima secara umum oleh manusia berdasarkan akal, wahyu, dan fitrah. Kebenaran itu dipraktekkan di dalam hati dan diyakini keshahihan dan keberadaannya secara pasti, dan ditolak segala sesuatu yang bertentangan dengan kebenaran itu.

Dalam ajaran Islam, aqidah Islam (al-aqidah al-Islamiyah) merupakan keyakinan atas sesuatu yang terdapat dalam apa yang disebut dengan rukun iman, yaitu keyakinan kepadaAllah, malaikat-Nya, kitab-kitab-Nya, rasulrasul-Nya, Hari Akhir,serta taqdir baik dan buruk. ${ }^{11}$ Akidah merupakan ilham yang tumbuh dengan sendirinya yang tak dapat dirasakan, tumbuh dari sebab-sebab yang terlepas dari pengaruh kemauan, sedang ilmu hasil penciptaan akal yang diperoleh dari memperlihatkan sesuatu secara mendalam. Akidah ini terkadangkadang tumbuh di dalam hati, kemudian

\footnotetext{
${ }^{11}$ Yunahar Ilyas, Kuliah Akidah Islam, (Yogyakarta: Lembaga Pengkajian dan Pengalaman Islam(LPPI), h. 1-10.
} 
penganutnya berusaha mempergunakan akal untuk membenarkan Akidah itu. ${ }^{12}$

Menurut Hasan al-Banna ruang lingkup pembahasan akidah Islam terkait dengan masalah Ilahiyat; illahiyat yaitu pembahsan tentang segala sesuatu yang berhubungan dengan Illah (Tuhan, Allah) seperti wujud Allah, nama-nama dan sifatsifat Allah, af'al Allah san lainlain.Nubuwat; nubuwat yaitu pembahasan tentang segala sesuatu yang berhubungan dengan Nabi dan Rasul, termasuk pembahasan tentang Kitab-kitab Allah, Mukjizat, karamat dan lain sebagainya.Ruhaniyat; ruhaniyat yaitu pembahasan tentang segala sesuatu yang berhubungan dengan alam metafisik seperti Malaikat, Jin, Iblis, Syaitan, Roh dan lain sebagainya.Selanjutnya berkaitan dengan persoalan Sam'iyyat; yaitu pembahasan tentang segala sesuatu yang hanya bisa diketahui lewat sam'i (dalil naqli berupa Al-Qur'an dan Sunnah) seperti alam barzakh, akhirat, azab kubur, tanda-tanda kiamat, surga neraka dan lain sebagainya.Berkaitan dengan sumber, sumber aqidah Islam adalah Alquran dan Sunnah. Artinya apa saja yang disampaikan oleh Allah dalam Al-Qur'an dan oleh Rasulullah dalam Sunnahnya wajib diimani (diyakini dan diamalkan).

Akal pikiran tidaklah menjadi sumber Akidah, tetapi hanya berfungsi memahami nash-nash yang terdapat dalam kedua sumber tersebut dan mencoba kalau diperlukan untuk membuktikan secara ilmiah kebenaran yang disampaikan oleh Al-Qur'an dan Sunnah, itu harus didasari oleh suatu kesadaran bahwa kemampuan akal sangat terbatas, sesuai dengan terbatasnya kemampuan semua makhluk

\footnotetext{
${ }^{12}$ Hasbi Ash-Shiddieqi, Sejarah dan Pengantar Ilmu Tauhid, (Semarang:Pustaka Rizki Putra), h. 39.
}

Allah. Akal tidak akan mampu menjangkau masail ghaibiyah (masalah ghaib), bahkan akal tidak akan mampu menjamgkau sesuatu yang tidak terkait dengan ruang dan waktu. Misalnya akal tidak akan mampu menjawab pertanyaan kekal itu sampai kapan? Atau akal tidak akan mampu menunjukkan tempat yang tidak ada didarat, diudara, dilautan dan tidak ada dimana-mana. Karena kedua hal tersebut tidak terkait dengan ruang dan waktu. Oleh sebab itu akal tidak boleh dipaksa untuk memahami hal-hal tersebut dan menjawab pertanyaan tentang segala sesuatu yang bersifat ghaib. Akal hanya perlu membuktikan jujurkah atau bisakah kejujuran si pembawa berita tentang halhal ghabi tersebutyang dibuktikan secara ilmiah oleh akal pikiran, hanya itu.

Menurut Syeikh Ali Thanthawi ada beberapa kaidah Akidah untuk mengetahui sejauh mana fitrah dan akal berperan dalam masalah Akidah sebagai berikut:

1. Apa yang saya dapat denag indra saya, saya yakini adanya, kecuali bila akal saya mengatakan"tidak"

berdasarkan pengalam masa lalu.

Misalnya, apabila saya pertama kali melihat sepotong kayudidalam gelas berisi air putihkehilahannya bengkok, atau melihat tiang-tiang listrik bergerak dilihat dari jendela kereta apiyang sedang berjalan, atau melihat fatamorgana, tentu saya akan membenarkannya. Tapi bila bukti kemudian hasil penglihatan indra saya itu salah, maka untuk kedua kalinya saya melihat yang sama, akal saya langsung mengatakan tidak demikian yang sebenarnya.

2. Keyakinan, disamping diperoleh dengan menyaksikan langsung, juga bisa melalui 
beritabyang diyakini kejujuran sipembawa berita itu.

Banyak hal yang sebenarnya belumkita saksikan kebenarannya. Misanya Anda belum pernah ke India, Brazil atau Mesir, tapiAnda meyakini negeri-negeri tersebut ada. Atau tentang fakta sejarah, tentang Daulah Abbasiyah, Umaiyah, tentang Kerajaan Majapahit dan lain sebagainya, Anda meyakini kenyataan sejarah itu bedasarkan berita yang Anda terima dari sumber yang dipercaya.

3. Anda tidak berhak memungkiri wujudna sesuatu, hanya karena Anda tidak bisa menjangkaunya dengan indra mata.

Kemampuan alat indra sangat terbatas, telinga tidak bisa mendengar suara semut dari jarak terdekat sekalipun, mata tidak bisa menyaksikan semut dari jauh. Di sebuah ruangan yang sepi Anda tak akan mendengar apa-apa, oleh sebab itu seseorang tidak bisa memungkiri wujudnya sesuatu hanyakarena indranya tiak bisa menyaksikannya.

\section{Seseorang hanya bisa menghkayalkan sesutauyang sudah dipernah dijangkau oleh inderanya.}

Khayal manusia pun terbatas, Anda tidak bisa mengkhayalkan sesuatu yang baru sama sekali.

5. Akal hanya bias menjangkau hal-hal yang hanya terkait dengan ruamg dan waktu.

Tatkala mata mengatakan bahwa tiang-tianga listrik berjalan waktu kita menyaksikannya melalui jendela kereta api akal dengan cepat mengoreksinya. Tapi apakah akal bisa memajami dan menjangkau segala sesuatu? Tidak.
Karena kemampuan akal pun terbatas, akal tidak bisa menjangkau sesuatu yang tak terkait ruang dan waktu seperti, Bisakah Anda menjelaskan kapan terjadi sesuatu peristiwa, kalau peristiwa itu tidak terjadai dulu, sekarang dan juga pada masa yang akan datang?

6. Iman adalah fitrah manusia

Setiap manusia memiliki fitrah mengimani adanya Tuhan. Pada saat sesorang mengaku bahwa dia tidak bertuhan, kehilangan harapan untuk hidup, padahal dia masih ingin hidup, fitrahnya akan menuntun diauntuk meminta kepada Tuhan. Bila anda masuk kedalam hutan dan terperosok kedalam lubang, pada anda kehilangan harapan untuk keluar dari lubang itu, Anda kan berbisik: Oh Tuhan! Sekalipun sebelumnya anda belum pernah menyebut nama Tuhan. Tapi firahnya itu hanya potensi adasar, yang perlu dikembnagkan dan dipelihara, karena fitrah bisa tertutup oleh macam-macam hal.

7. Kepuasan material didunia sangat terbatas.

8. Keyakinan tentang Hari Akhir adalah konsekuensi logis dari keyakinan tentang adanya Tuhan.

Jika kita beriman kepada Allah, tentu Anda beriman atas sifat-sifatNya, termasuk sifat "adil" . kalau tidak ada kehidupan lain diakhirat, bisakah keadilan Allah itu terlaksankan? Bukankah setiap penjahat harus menanggung akibat dari perbutannya? Bukannkah tidak semua orang yang berbuat baikmerasakan hasil kebaikannya itu? Oleh sebab itu, iman Anda dengan Allah menyebabkan Anda beriman dengan adanya alam lain sesudah alam dunia ini yaitu Hari Akhir. 
Ibadah (عبادة) secara etimologi berarti merendahkan diri serta tunduk. Di dalam syara', ibadah mempunyai banyak definisi, tetapi makna dan maksudnya satu. Diantara definisinya :

a. Ibadah adalah merendahkan diri kepada Allah , yaitu tingkatan ketundukan yang paling tinggi disertai dengan rasa mahabbah (kecintaan) yang paling tinggi;

b. Ibadah ialah sebutan yang mencakup seluruh apa yang dicintai dan diridhai Allah , baik berupa ucapan atau perbuatan, yang dzahir maupun bathin;

c. Menurut Syaikhul Islam Ibnu Taimiyyah Rahimahullah : Ibadah adalah segala sesuatu yang mencakup semua hal yang dicintai dan diridhai Allah Ta'ala, baik berupa ucapan dan amalan, yang nampak dan yang tersembunyi.1

Akidah menempati posisi terpenting dalam ajaran agama Islam. Ibarat sebuah bangunan,maka perlu adanya pondasi yang kuat yang mampu menopang bangunan tersebut sehingga bangunan tersebut bisa berdiri dengan kokoh. Demikianlah urgensi akidah dalam Islam, aqidah seseorang merupakan pondasi utama yang menopang bangunan keislaman pada diriorang tersebut. Apabila pondasinya tidak kuat maka bangunan yang berdiri diatasnya punakan mudah dirobohkan.Selanjutnya Ibadah yang merupakan bentuk realisasi keimanan seseorang, tidak akan dinilai benar apabila dilakukan atas dasar akidah yang salah. Hal ini tidak lain karena tingkatkeimanan seseorang adalah sangat bergantung pada kuat tidaknya serta benar salahnyaakidah yang diyakini orang tersebut. Sehingga dalam diri seorang muslim antara akidah,keimanan serta amal ibadah mempunyai keterkaitan yang sangat kuat antara ketiganya.Muslim apabila akidahnya telah kokoh maka keimanannya akan semakin kuat, sehinggadalam pelaksanaan praktek ibadah tidak akan terjerumus pada praktek ibadah yang salah.Sebaliknya apabila akidah seseorang telah melenceng maka dalam praktek ibadahnya punakan salah kaprah, yang demikian inilah akan mengakibatkan lemahnya keimanan.Pondasi aktifitas manusia itu tidak selamanya bisa tetap tegak berdiri, maka dibutuhkanadanya sarana untuk memelihara pondasi yaitu ibadah. Ibadah merupakan bentukpengabdian dari seorang hamba kepada Allah.Ibadah dilakukan dalam rangka mendekatkandiri kepada Allah untuk meningkatkan keimanan dan ketaqwaan terhadap Allah.Manusia sebagai makhluk yang paling sempurna, sejak kelahirnya telah dibekali denganakal pikiran serta perasaan (hati).Manusia dengan akal pikiran dan hatinya tersebut dapatmembedakan mana yang baik dan mana yang benar, dapat mempelajari bukti-buktikekuasaan Allah, sehingga dengannya dapat membawa diri mereka pada keyakinan akankeberadaanNya.Oleh karena itu, tidak ada alasan bagi manusia untuk tidak mengakuikeberadaan Allah.karena selain kedua bekal yang dimiliki oleh mereka sejak lahir,Allah juga telah memberikan petunjuk berupa ajaran agama yang didalamnya berisikantuntunan serta tujuan dari hidup mereka di dunia.Ibadah mempunyai hubungan yang erat dengan aqidah, yaitu sebagai berikut:

a. Ibadah adalah hasil daripada aqidah yaitu keimanan terhadap Allah sebenarnya 
yangtelah membawa manusia untuk beribadat kepada Allah.

b. Aqidah adalah asas penerimaan ibadah yaitu tanpa aqidah perbuatan seseorang manusia bagaimana baik pun tidak akan diterima oleh Allah.

Aqidah merupakan tenaga penggerak yang mendorong manusia melakukan ibadat sertamenghadapi segala cabaran dan rintangan.Akidah adalah merupakan pondasi utama kehidupan keislaman seseorang. Apabila pondasiutamanya kuat, maka bangunan keimanan yang terealisasikan dalam bentuk amal ibadahorang tersebut pun akan kuat pula.Amal ibadah tidak akan bisa benar tanpa dilandasi akidah yang benar. amal ibadah dinilai benar apabila dilakukan hanya untuk Allah semata denganittiba’ Rasul.

Manusia diberi bekali akal pikiran agar dengan akal pikiran tersebut mereka dapatmembedakan mana yang hak dan mana yang batil, mempelajari tanda-tanda kekuasaanAllah, menganalisa hakikat kehidupannya sehingga dia tahu arah dan tujuan dirinyadiciptakan di dunia. Akal pikiran dan perasaan inilah yang membedakan manusia denganmakhlukmakhluk lain. Oleh karena itu manusia dipercaya untuk menjadikhalifahAllah dibumi.Sementara berkaitan dengan akhlak ada dua pendekatan yang dapat digunakan untuk mendefinisikan akhlak, yaitu pendekatan linguistik (kebahasaan), dan pendekatan terminologi (peristilahan). ${ }^{13}$

\section{Pendekatan Linguistik (Kebahasaan)}

\footnotetext{
${ }^{13}$ H. Mahmud Yunus,Kamus Arab Indonesia, (Jakarta:Hidakarya Agung,1972), h. 274.
}

Berasal dari bahasa Arab, yaitu isim mashdar (bentuk infinitive) yaitu merupakan isim jamid atau isim ghair mustaq, yaitu isim yang tidak memiliki akar kata, melainkan kata tersebut memang telah demikian adanya.

\section{Pendekatan Terminologi (Peristilahan)}

Sifat yang tertanam dalam jiwa yang mendorongnya untuk melakukan perbuatan tanpa memerlukan pemikiran dan pertimbangan.

Dapat diambil kesimpulan bahwa ilmu akhlak adalah ilmu yang membahas tentang perbuatan manusia yang dinilai baik dan buruk.Dalam Mu'jam al-Wasith disebutkan ilmu akhlak adalah:

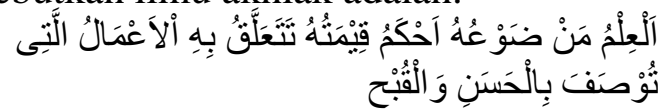

(Ilmu yang objek pembahasannya adalah tentang nilai-nilai yang berkaitan dengan perbuatan manusia yang dapat disifatkan dengan baik atau buruk). ${ }^{14}$

Salah satu fungsi akhlak adalah untuk menopang keimanan.Agar iman seseorang relative stabil, perlu ditopang oleh pelaksanaan akhlak yang konsisten. ${ }^{15}$ Dasar pendidikan akhlak bagi seorang muslim adalah aqidah yang benar terhadap alam dan kehidupan, Karena akhlak tersarikan dari aqidah dan pancaran dirinya. seorang beraqidah dengan benar, niscahya akhlaknya pun akan benar, baik dan lurus. Begitu pula sebaliknya.

Aqidah seseorang akan benar dan lurus jika kepercayaan dan keyakinanya terhadap alam juga lurus dan benar. Karena barang siapa mengetahui sang

\footnotetext{
${ }^{14}$ Ibid., h. 346.

${ }^{15}$ Abudin Nata, Akhlak Taswuf,
} (Jakarta:Raja Grafindo Persada,2002), h. 5. 
pencipta dengan benar, niscahya ia akan dengan mudah berperilaku baik sebagaimana perintah allah. Sehingga ia tidak mungkin menjauh bahkan meninggalkan perilaku-perilaku yang telah ditetapkanya. Pendidikan akhlak yang bersumber dari kaidah yang benar merupakan contoh perilaku yang harus diikuti oleh manusia. Mereka harus mempraktikanya dalam kehidupan mereka, karena hanya inilah yang menghantarkan mereka mendapatkan ridha allah dan atau membawa mereka mendapatkan balasan kebaikan dari Allah.

Akhlak merupakan tingkahlaku yang dipengaruhi oleh nilai-nilai yang diyakini oleh seseorang dan sikap yang menjadi sebahagian daripada keperibadiannya. Nilai-nilai dan sikap itu pula terpancar daripada konsepsi dan gambarannya terhadap hidup. Dengan perkataan lain, nilai-nilai dan sikap itu terpancar daripada aqidahnya yaitu gambaran tentang kehidupan yang dipegang dan diyakininya. ${ }^{16}$ Aqidah yang benar dan gambaran tentang kehidupan yang tepat dan tidak dipengaruhi oleh kepalsuan, khurafat dan falsafah-falsafah serta ajaran yang palsu, akan memancarkan nilai-nilai benar yang murni di dalam hati. Nilai-nilai ini akan mempengaruhi pembentukan sistem akhlak yang mulia. Sebaliknya, jika aqidah yang dianuti dibina di atas kepalsuan, maka ia akan memancarkan nilai-nilai buruk di dalam diri dan mempengaruhi pembentukan akhlak yang buruk.

Akhlak yang baik dan akhlak yang buruk, merupakan dua jenis tingkah laku yang berlawanan dan terpancar daripada dua sistem nilai yang berbeda. Keduaduanya memberi kesan secara langsung

\footnotetext{
${ }^{16}$ Yunahar Ilyas, Op.cit., h. 3.
}

kepada kualitas individu dan masyarakat. Individu dan masyarakat yang dikuasai dan dianggotai oleh nilai-nilai dan akhlak yang baik akan melahirkan individu dan masyarakat yang sejahtera. Begitulah sebaliknya jika individu dan masyarakat yang dikuasai oleh nilai-nilai dan tingkahlaku yang buruk, akan porak peranda dan kacau balau.

Alquran juga menggambarkan bagaimana aqidah orang-orang beriman, kelakuan mereka yang mulia dan gambaran kehidupan mereka yang penuh tertib, adil, luhur dan mulia. Berbanding dengan perwatakan orang-orang kafir dan munafiq yang jelek. Gambaran mengenai akhlak mulia dan akhlak tercela begitu jelas dalam perilaku manusia sepanjang sejarah. Alquran juga menggambarkan bagaimana perjuangan para rasul untuk menegakkan nilai-niai mulia dan murni di dalam kehidupan dan bagaimana mereka ditentang oleh kefasikan, kekufuran dan kemunafikan yang cuba menggagalkan tertegaknya dengan kukuh akhlak yang mulia sebagai teras kehidupan yang luhur dan murni itu. ${ }^{17}$

\section{KESIMPULAN}

Tauhid berarti mengesakan Allah dalam hal mencipta, menguasai, mengatur dan memurnikan (mengikhlaskan) peribadahan hanya kepada-Nya, meninggalkan penyembahan kepada selain-Nya serta menetapkan asma'ul husna , sifat al-'ulya bagi-Nya, dan mensucikan-Nya dari kekurangan dan cacat.

Secara klasifikasi, tauhid dibagi kepada tauhid Rububiyah sebagai keyakinan bahwa hanya allah-lah satu-

\footnotetext{
${ }^{17}$ Muhammad Daud Ali, Pendidikan Agama Islam, (Jakarta: Raja Grafindo Persada, 2006), h. 199.
} 
satunya pencipta, pemilik, pengendali alam raya yang dengan takdirnya-Nya ia menghidupkan dan mematikan serta mengendalikan alam semesta ini; tauhid Uluhiyah merupakan kepercayaan sepenuhnya bahwa Allah yang berhak menerima semua peribadatan makhluk, dan hanya Allah yang sebenarnya yang harus disembah; dan Tauhid Ubudiyah sebagai pengabdian kepada allah dengan menyembah kepada-Nya.

Hubungan antara aqidah dengan ibadah dan akhlak bermakna bahwa seseorang yang berakidah dengan benar pasti dia beribadah dengan benar dan orang yang beribadah dengan benar pasti dia berakhlak dengan benar.Artinya, buah akidah ialah ibadah, buah ibadah ialah akhlakul karimah. Akidah sebagai pondasi utama yang teguh dan pasti, yang tidak ada keraguan sedikit pun bagi orang yang meyakininya; ibadah mencakup semua hal yang dicintai dan diridhai Allah, baik berupa ucapan dan amalan, yang nampak dan yang tersembunyi, tentang nilai-nilai yang berkaitan dengan perbuatan manusia yang dapat disifatkan dengan baik atau buruk, tentang nilai-nilai yang berkaitan dengan perbuatan manusia yang dapat disifatkan dengan baik atau buruk.

\section{DAFTAR KEPUSTAKAAN}

Abdul Aziz bin Muhammad Ali Abdul Lathif, 1998,Pelajaran Tauhid untuk Tingkat Lanjutan, (Jakarta:Darul Haq).

Zainuddin, 1996,Ilmu Tauhid Lengkap(Jakarta: Penerbit Rineka Cipta).

Yunahar Ilyas, 2001, Kuliah Akidah Islam, (Yogyakarta: Lembaga Pengkajian dan Pengalaman Islam(LPPI).
Hasbi ash-Shiddieqi, 1999, Sejarahdan Pengantar Ilmu Tauhid, (Semarang: Pustaka Rizki Putra).

Mahmud Yunus, 1972, Kamus Arab Indonesia, (Jakarta:Hidakarya Agung).

Abudin Nata, Ahlak Taswuf, 2002, (Jakarta:Raja Grafindo Persada).

Yunahar Ilyas,Kuliah Ahklak, 2007, (Yogyakarta:Lembaga Pengkajian dan Pengalaman Islam(LPPI), cet. IX.

Muhammad Daud Ali, Pendidikan Agama Islam, 2006, (Jakarta: Raja Grafindo Persada). 